JOURNAL OF SECURITY AND SUSTAINABILITY ISSUES ISSN 2029-7017 print/ISSN 2029-7025 online

2019 December Volume 9 Number 2 http://doi.org/10.9770/jssi.2019.9.2(18)

\title{
MEDIATION IN CIVIL MATTERS AS AN EXAMPLE OF THE METHOD USED IN LEGAL SECURITY MANAGEMENT AND OPTIMIZATION OF COSTS OF PROCEEDINGS
}

\author{
Marcin Jurgilewicz ${ }^{1}$, Krystyna Kmiotek ${ }^{2}$, Robert Dankiewicz ${ }^{3}$, Andrzej Misiuk ${ }^{4}$ \\ ${ }^{1,2,3}$ Rzeszów University of Technology, Aleja Powstańców Warszawy 12, 35-959 Rzeszów, Poland \\ ${ }^{4}$ University of Warsaw, Krakowskie Przedmieście 26/28, 00-927 Warszawa, Poland \\ E-mails:1'm.jurgilewicz@prz.edu.pl, ${ }^{2} k r y s i a k k @ p r z . e d u . p l,{ }^{3}$ rdankiew@prz.edu.pl, ${ }^{4}$ amisiuk@wp.pl
}

Received 11 February 2019; accepted 28 September 2019; published 30 December 2019

\begin{abstract}
Mediation is an example of one of the alternative methods of resolving legal disputes. Its use is becoming more and more common, and the very idea of using mediation institutions to resolve legal disputes brings many benefits to conflicting parties, which include speed of proceedings or its cheaper costs. On the basis of national legislation, mediation has become a universal institution because it has been regulated in both public and private law. The next step of the legislator was to equip the mediator in civil matters with various methods through which he can conduct mediation proceedings. Therefore, the mediator conducts mediation using various methods aimed at amicable settlement of the dispute, including by supporting the parties in formulating their settlement submissions or at the mutual request of the parties, it may also indicate ways of resolving the dispute which are not binding for the parties. However, the success of mediation is determined not only by the will of the parties, but also by the way the mediator conducts this procedure, which is characteristic of the conflict management formula. In turn, the instruments at the disposal of the mediator in civil matters, in addition to their real impact on increasing the number of mediation proceedings and settlements concluded before the mediator, which is an example of the desired solution, also imply other legal consequences, including optimization of the costs of the process. Therefore, in addition to financial benefits for parties benefiting from mediation by the society, it is worth considering the methods of conducting this procedure in civil matters, which are examples of tools for managing legal security.
\end{abstract}

Keywords: security; management; mediation; costs and fees

Reference to this paper should be made as follows: Jurgilewicz, M., Kmiotek, K., Dankiewicz, R., Misiuk, A. 2019. Mediation in civil matters as an example of the method used in legal security management and optimization of costs of proceedings, Journal of Security and Sustainability Issues 9(2): 595-602. http://doi.org/10.9770/jssi.2019.9.2(18)

JEL Classifications: O35

Additional disciplines: law

\section{Introduction}

Inevitable part of any activity is conflicts, which hinder development of any activities (e.g. Kaźmierczyk, Chinalska, 2018; Kazansky, Andrassy, 2019; Vinichenko et al., 2019; Bublienė et al., 2019). Mediation, as a method of settling legal disputes alternative to trial, is an example of a legal institution which, in a normative way, finds its power in nearly every branch of law. It can be applied not only on the basis of private law, that is in civil-law cases, but also under public law (e.g. in criminal cases). In turn, due to the development of this institution in Poland, from June 2017 it is also possible to apply mediation in administrative matters. By virtue of the amendment introduced to the Act of 14 June 1960 The Code of Administrative Procedure, mediation was incorporated into the administrative procedure (Articles $96^{\mathrm{a}}-96^{\mathrm{n}}$ of the Code), which is a desirable solution, fully embedding the indicated legal institution in the administrative law system. Similarly, progressive changes were made in the Act of 30 August 2002 on proceedings before administrative courts (UPPSA), which also 
concern mediation proceedings (articles $116^{\mathrm{a}}-116^{\mathrm{e}}$ of UPPSA).

Nowadays, therefore, the relatively broad scope of the use of mediation in Polish legislation makes this institution universal. However, in view of the fact that mediation in civil matters has been in force for over a decade, and that on 1 January 2016 - by virtue of the Act of 10 September 2015 amending certain acts in connection with the promotion of amicable dispute resolution - art. 1833 a was introduced to the Act of 17 November 1964 The Code of Civil Procedure (CCP), outlining the methods of mediation, it is worth presenting some reflections in this respect, because this solution is an example of a legal tool that can be successfully used in the subject of managing legal security. In turn how the justification to this law demonstrates, the proposed change was aimed at increasing the effectiveness of mediation procedures and the number of settlements concluded in their course, especially in disputes in which the parties appear without a professional representative.

\section{Legal safety management}

In the scientific literature, legal security is defined as a kind of state that is achieved by means of a law, in which not only the good life of the individual - but also his interests - are protected as completely and effectively as possible. The above-mentioned definition allows to conclude that this constituted law, in particular universally binding norms, is an example of tools to prevent chaos in relations between individuals, as well as to maintain social order, because they are designed to safeguard life's goods as well as human interests, mainly through the use of state coercion. In turn, due to the fact that mediation, being an example of a legal institution enabling conflicted parties to independently work out a consensus, and thus resolve the resulting conflict, it can be assumed that chaos in interpersonal relations can be solved not only by applying solutions with state coercion (Jurgilewicz, Dana 2015). In turn, the problem of managing legal security in the considered aspect should be seen in terms of a complex process consisting mainly of public and private entities, including individual persons - in this case, it will also be mediators - activities aimed at achieving specific goals. In the case of mediation, it will therefore be an attempt to resolve the conflict between the parties by means of a settlement, which is to serve the specific tools currently available to mediators in civil matters (Sebenius, 1992).

\section{The legal conditions of mediation in civil matters}

The development of mediation in civil matters in Poland was initiated primarily by calling Member States during the 1999 European Council meeting to create alternative, out-of-court procedures, followed by the adoption in May 2000 of conclusions on alternative dispute resolution in civil and commercial matters, due to the fact that the establishment of basic principles in this matter is a welcome step towards enabling the proper development and operation of out-of-court dispute resolution procedures in civil and commercial matters, which helps simplify and improve access to justice. In reference to this, the publication in 2002 of the Green Book of the European Commission on alternative methods for settling civil and commercial disputes initiated an international discourse on the need and manner of regulating mediation and other methods of conciliation in Community law. One of the effects of these events was undertaking in 2003 by the Codification Commission for the Civil Code, operating under the Polish Ministry of Justice, works on the institution of mediation as part of the arbitration tribunal problem group, which completed the legislative proposal presented in 2004 before the Polish Sejm, and finally the adoption on July 15, 2005 of the Act of 28 July 2005 amending the Act on the Code of Civil Procedure (CCP) and certain other laws. This Act, however, entered into force only after several months - to be exact, on 10 December 2005 - when mediation was officially instituted in civil procedure. Mediation in the CCP was contained in 16 articles (articles $183^{1}-183^{15}$ of the CCP) where it is discussed in detail, although it is also referred to in: art. $98^{1}$, art. $103 \S 2$, art. $104^{1}$, art. $202^{1}$, art. $259^{1}$, art. 436, art. $445^{2}$, and art. $570^{2}$ of the same Act. Mediation in civil procedure is applicable in civil cases, so it can be successfully used mainly in family, neighbor, economic or consumer disputes. In addition, the introduction of mediation to the CCP has not breached the applicable normative regulation regarding conciliation proceedings (articles 184-186 of the CCP), or the principles of court settlements, with the exception of liquidation of conciliation in divorce cases, replacing it with the possibility of referring parties to mediation when there are views on the maintenance of marriage (art. 436 of the CCP). Mediation is marked by a number of flagship principles, some of which include: voluntariness 
(will), confidentiality, impartiality, neutrality, and acceptability. The principle of voluntariness stems from art. $183^{1} \S 1$ of the CCP and is a key principle of mediation, characterized mainly by the free will of the parties to the proceedings not only as regards the consent to join the mediation as such, but also the active participation in it and the possibility of resignation from it at any stage. Although there is a risk of the party being charged with the costs of the process as a result of an unjustified refusal in mediation proceedings, this is nevertheless possible only when the party has previously agreed to mediation. The principle of voluntariness corresponds with the principle of the autonomy of the will of the parties and their conscious participation in mediation, the reason for which it is important that the party is aware of the factual circumstances of the dispute, and even more importantly, of the effects of the settlement before the mediator. The individual, being aware of his or her procedural situation, as well as of the procedural consequences in which he or she participates, will approach mediation with a greater security and certainty, which only reinforces compliance with the principle of voluntariness. In turn, although the voluntariness of mediation is seen as its advantage, in the case of refusal by the party to be subject to mediation or abandoning his or her commitment to the previously concluded mediation agreement, it becomes a certain disadvantage, causing e.g. the extension of the time of resolution of the case, which could be terminated by adjudication (Jurgilewicz, Dana 2015).

Another principle of the mediation process is confidentiality. It stems from art. $183^{4} \S 1$ of the CCP and comes down, mainly, to the obligation of not providing information that was exchanged between the parties to the proceedings - or the party and the mediator - to third parties without the prior consent of the party or parties. This rule is further reinforced by art. $183^{4} \S 3$ of the CCP, which points out that it is irrelevant to refer in the course of proceedings before a court or arbitral tribunal to settlement proposals, proposals for mutual concessions or other statements submitted in the mediation process. The recipient of this principle is, above all, the mediator, because in accordance with art. $183^{4} \S 2$ of the CCP, he or she is obliged to keep confidential the facts learned about the mediation, unless the parties have released him or her from this obligation. In addition, pursuant to art. $259^{1}$ of the CCP, the mediator must not be a witness of the facts that he or she has learned in the course of mediation, unless he or she has been released from this obligation by both parties. As far as the parties to the mediation process are concerned, despite the fact that the CCP imposes no direct obligation of confidentiality, if such an obligation is included in the mediation contract - or if it is included in the mediation center's regulations - it would be appropriate to apply art. $72^{1} \S 1$ of the Act of 23 April 1964 The Civil Code. This Act states that if, during the negotiations, the party has made available information subject to confidentiality, the other party must not disclose or pass it on to third parties, nor use this information for his or her own purposes, unless the parties have agreed otherwise (Morek 2007).

Thus, the principle of confidentiality seems to have a significant impact on the popularity of mediation, given that the attempt to reach by the mediator a source of conflict allowing a settlement would not be possible if the parties were afraid that the content of their conversations during mediation would be revealed. Confidentiality is, therefore, a guarantee of the parties' voluntary accession to mediation, as well as its effectiveness and providing the parties with equal treatment in the course of the mediation process. Other mediation principles, such as impartiality, neutrality and professionalism, refer strictly to the mediator, whose legal status will be analyzed later in this study. At this point, it is worth noting that, pursuant to art. $183^{1} \S 2$ of the CCP, in conjunction with art. $183^{6} \S 1$ of the CCP, mediation in civil cases may be, as a rule, carried out on the basis of a court order sending the parties down the road of mediation (court-ordered mediation) or a contract for mediation concluded by the parties (contractual mediation), whereby such an agreement may also be concluded by expressing consent to mediation in response to a request for it made by the other party. The presented division into different types of mediation allows to distinguish potential initiators of the mediation process. Therefore, initiating mediation can come from both parties, one of them, or as a result of a court initiative, which in practice has the form of court-ordered mediation (Jurgilewicz, Dana 2015).

However, regardless of the basis for initiating mediation, its effectiveness depends on the actual approval of the settlement reached during the course of the mediation proceedings by the court. In accordance with art. $183^{12} \S 1-3$ of the CCP, a report is drafted from the course of mediation, in which data such as: place and time of mediation, first name, last name and addresses of the parties, name and address of the mediator, and the result 
of mediation, are included. The report is signed by the mediator, and when the parties have reached a settlement before the mediator, it is either included in the protocol or annexed to it. The parties are obliged to sign a settlement, while the impossibility of signing it is stated by the mediator in the protocol. In turn, submitting signatures under a settlement by the parties constitutes the consent to apply to the court for its approval, of which the mediator is supposed to inform the conflicted parties. The mediator is also obliged to provide the parties with a copy of the protocol. However, the competent court immediately conducts proceedings regarding the approval of the settlement, and if it is enforceable, the court approves it by giving it an enforcement clause; in other cases, it approves it by virtue of the decision made in a closed session. Nevertheless, there is a risk of refusal to issue a declaration of enforceability or approval of a settlement concluded before the mediator, either in whole or in part, if it is contrary to the law or principles of social coexistence or is aimed at circumventing the law, or if it is incomprehensible or contradictory (Jurgilewicz 2018).

\section{The mediator and methods of mediation in civil matters}

The mediator in civil matters should be an impartial person, which results directly from art. $183^{3} \S 1$ of the CCP. The characteristics of the mediator are also important, given that his or her substantive preparation for conducting mediation increases the success of reaching a settlement by the parties. Therefore, a good mediator will be someone who can create a comfortable atmosphere for parties to engage in dialogue, and more importantly, who can skillfully encourage these parties to exchange relevant information, and consequently, evaluate the chances of the conflict being resolved. The mediator should have solid negotiating skills, and also feel and be able to distinguish between what the parties want to achieve and what they actually can achieve. Particularly important in this aspect is the continuous improvement of qualifications by the mediator and the constant expansion of knowledge, particularly in the field of law and psychology, but also with respect to different ways of negotiation, etc. However, this profile in practice often becomes difficult to fulfill, especially that in the light of national legislation, formal requirements that are imposed on the candidates for mediators are not excessively demanding. According to art. $183^{2} \S 1-2$ of the CCP, a mediator in civil cases can be a natural person with full legal capacity and full public rights, but he or she cannot be a retired judge (Jurgilewicz, Dana 2015).

It is worth noting that at the stage of legislative works, concerns were expressed that too liberal solutions regarding the requirements for candidates for mediators may affect the quality of mediation itself. Nevertheless, the current requirements for the candidates to meet, on the one hand, reflect the civilian principle of the autonomy of the parties' will (especially regarding the choice of mediator), and on the other hand, they give rise to a risky situation in which mediation is carried out by persons who are either inexperienced or unprepared for this role, which may then undermine reaching a settlement. This is a specific kind of risk because, in accordance with art. $183^{8} \S 2$ of the CCP, the court may refer the parties to mediation only once in the course of proceedings. The current solutions regarding the qualification of candidates for the job of a mediator, which are highly liberal in nature, may sometimes be a disadvantage, especially in economic matters, where the parties are entrepreneurs who would expect professionalism on the part of the mediator conducting their mediation proceedings (Lax, Sebenius 1986).

At the same time, approval should be expressed for the statement that, for the sake of including mediation in the justice system, the qualifications of mediators should not be based solely on their characteristics (understood as personality traits), because it requires from them not only openness and the ability to establish interpersonal relationships, but also a thorough knowledge of mediation procedures and techniques. Therefore, choosing a competent mediator is not just a matter of responsibility for the very party, but it also entails a far-reaching significance for the justice system as a whole. This position closely coincides with the authors view on this issue. The mediator should undergo at least basic training in mediation before being allowed to handle mediation proceedings. In addition, referring still to the mediator's qualification in civil matters, it should be noted that while the requirement of full legal capacity of such a person does not raise any doubts per se, the requirement of full public rights may indeed give rise to certain problems - not only of legal, but also factual nature. By specifying public rights, the legislator indicated the circumstances connected with their deprivation, which prompts an optional criminal remedy, in the case of sentencing for imprisonment for a period of not less than 
3 years for an offense committed as a result of a motive deserving special condemnation. Then, in the case of a decision depriving public rights, the court notifies of this fact, e.g. a public administration body that is competent for the last place of residence or stay of the convicted person. However, since the relevant data are stored in the National Criminal Register (KRK), they are, basically, unavailable to third parties. In practice, therefore, the parties to the mediation process lack the freedom to verify the mediator's information in the discussed scope, except to receive an appropriate statement from such a person (in so far as they are aware of it) or to request submitting a KRK certificate, which would be a very uncomfortable move both for the parties and for the mediator already at the outset of the proceedings, plus it would generate unnecessary costs and a waste of time (Jurgilewicz, Dana 2015).

Furthermore, it is also not clear how to treat a settlement made before a mediator who has been deprived of public rights. And although it seems rational to hold a view that - despite the alleged violation of the content of art. $183^{2} \S 1$ of the CCP - such a statement can be deemed as valid since it is the parties themselves who should decide its content, when considering the wording of the new art. $183^{3} \mathrm{a}$, which empowers the mediator to support the parties in the formulation of settlement proposals, and even to indicate ways of resolving the dispute, it appears that such a normative gap, due to the procedural prudence of the parties, should be clearly resolved by the legislator. Likewise, the omission of a normative solution regarding the citizenship of a mediator in civil matters seems to be another kind of a legal loophole. The same goes for the participation of the interpreter of a mediator who is a foreign citizen, given that, in accordance with art. $183^{4} \S 1-2$ of the CCP, mediation proceedings are implicit and the mediator is obliged to keep confidential the facts that he or she has learned in connection with mediation, unless the parties have released him or her from this obligation. The recipient of this norm is, therefore, the mediator, not his or her potential interpreter. There is also a lack of legible normative guidance, e.g. a judge who is not a Polish citizen and who is not retired can be a mediator because the solution contained in art. $183^{2} \S 2$ of the CCP only generally indicates that the mediator cannot be a judge, unless he or she is retired, which also seems too broadly outlined a solution. Due to the fact that the success of mediation depends largely on the mediator, this person is obliged to conduct mediation professionally. It is worth noting that the Social Council for Alternative Methods of Resolving Conflicts and Disputes, operating under the Polish Minister of Justice, developed standards for conducting mediation by the mediator, which were adopted on June 26, 2006. And although they do not constitute a source of universally binding law, nor can they serve as the basis for making legal claims by third parties, they nevertheless provide a specific nature of guidelines and recommendations for mediators. The authors of these standards were guided, in particular, by the following objectives: assisting in the practice of mediation, providing greater security for both mediation parties and mediators, increasing public trust for mediation and assistance to candidates planning to become mediators. Nine main standards are singled out in the content, and it results from them that the mediator should, in particular: ensure voluntary participation in the mediation and settlement process, ensure confidentiality of mediation, have a high level of professional qualifications, be neutral to the subject of the dispute and impartial to the participants of the proceedings, reliably inform the parties about the essence and course of mediation, cooperate with other specialists for the benefit of mediation proceedings, as well as provide the parties with the right place to conduct mediation (Jurgilewicz, Dana 2015).

The European Code of Conduct for Mediators is similar in nature, which results in the distinction of the requirement of impartiality, consisting in the lack of bias and equal treatment of mediation participants and avoiding any activities that may appear seemingly biased and affect the neutrality of one of the parties, or that exert any pressure on the parties' acceptance of the settlement, let alone the conciliation of the specific content. Similarly, the 2003 The Code of Ethics for Mediators provides another example of a document referring to the principle of impartiality, neutrality and professionalism of the mediator, which in fact suggests the constant acquisition of knowledge and skills by such a person, and it especially prohibits contact with parties geared towards their own benefit. This document also defines the principle of acceptability both for the acceptance of a mediator by the parties, as well as for conducting mediation based on mutual respect and in respect of the dignity of the parties and the mediator.

From a practical point of view, the most important principles expected of the mediator are, primarily, the preser- 
vation of neutrality and impartiality. The principle of impartiality contained in art. $183^{3}$ of the CCP imposes on the mediator the same obligation when conducting mediation proceedings, whereas the principle of neutrality should be associated with the obligation of lack of bias and interest in the resolution of the case, as well as an independence of the mediator during the mediation process. It seems, however, that in the case of inequalities between parties to the dispute arising for various reasons, the mediator may take measures aimed at leveling the parties' chances by allowing the weaker party to become aware of stronger aspects of his or her position. In turn, the problem of, for example, the mediator providing legal information or issuing a legal opinion regarding the occurrence of possible consequences in the case covered by mediation proceedings may be questionable. The problem is important in so far as, with the relatively loose requirements of the mediator in civil matters, that person is not required to have legal knowledge. However, this may prompt this person to offer erroneous legal suggestions, which is all the more realistic in the light of art. $183^{3 \mathrm{a}}$ of the CCP.

As far as methods of mediation are concerned, the legislator indicates that the mediator has the right to mediate by using various instruments (methods, styles) during the mediation process, with a view to amicably resolving the dispute, including by supporting parties in formulating settlement proposals and the right to point out possible dispute resolutions, which are nevertheless not binding for the parties. The relatively new art. $183^{3} \mathrm{a}$ of the CPP enables mediation to be conducted using various techniques, and the proposals presented by the mediator are not binding for the parties, so the decision as to how to resolve a given dispute and conclude a specific content remains only in the will of the parties. Furthermore, as clearly stems from the justification to the draft law amending the Act - the Code of Civil Procedure and certain other acts in connection with the promotion of amicable dispute resolution methods, the proposed change would primarily aim to increase the effectiveness of mediation procedures and the number of settlements concluded in their course, especially in disputes in which the parties appear without a professional representative. This change, thus, strengthens the role of the mediator, who can explain to the parties their legal situation, present alternative solutions or propose submitting different variations of resolution. The legislator allows such a possibility within the framework of an open mediation formula, which is nevertheless initiated at the mutual request of the parties and with the approval of the mediator, as well as when the parties cannot independently work out the terms of the settlement. Additionally, in the justification for the above-mentioned project, the Act also indicates that the mediator has no right to order the parties to terminate the dispute in any particular way, nor can he or she exert any pressure on the parties, whereas the parties themselves have the right to receive the fullest possible information in order to allow them to make a fully aware and satisfactory decision. The mediator is also not legally required to conduct mediation using the method specified in art. $183^{3} \mathrm{a}$ of the CCP. Therefore, the amendment of the CCP with regard to methods of mediation in civil cases in practice allows the use of two styles, as defined in the scholarly literature. Mediation can be either conventional (facilitative), in which the mediator offers assistance to the parties in resolving their dispute and reaching a settlement although the parties themselves suggest ways of its resolution, or evaluative, in which the mediator assessing the legal situation of the parties and predicting court resolution in the case suggests ways to resolve the conflict (Ryskin 1996).

Although mediation in civil matters remains a voluntary process, and the proposals submitted to the parties by the mediator are in no way binding on the parties, nonetheless change in the CCP makes mediation more practical. With that being said, the profile of the mediator is the factor that will ultimately determine the success or failure of this solution. In practice, parties often expect to receive a concrete proposal of resolving their dispute, so that not only the personal traits of the mediator, but also his or her professional knowledge, will be decisive. According to the authors of this paper, the change in question, on the one hand, allows to increase the popularity of mediation, further propelled by the introduction of art. $183^{3 \mathrm{a}}$, and on the other hand, triggers the need to start a discussion on the proposal of establishing an institution such as a corporation of mediators so that their activities can become more professional.

On the other hand, when referring to the costs of mediation, which includes the mediator's remuneration, as well as expenses incurred by him, in accordance with generally applicable law in matters of property rights, the mediator's remuneration is $1 \%$ of the value of the subject of the dispute, but not less than PLN 150. and no more than 2000 PLN. for all mediation proceedings. In matters of property rights, in which the value of the subject 
of the dispute cannot be determined, as well as in cases of non-property rights, the mediator's remuneration for conducting mediation proceedings is PLN 150 for the first meeting, and PLN 100 for each subsequent meeting, not more than 450 in total. zł. The refund shall cover documented and necessary expenses of the mediator incurred in connection with the mediation to cover the costs of: journeys - in the amount and under the conditions set out in the provisions on the amount and conditions for determining the amounts due to an employee employed in a state or local government unit of the budgetary sphere for business trips; renting a room necessary to conduct a mediation meeting, not exceeding PLN 70. for one meeting, as well as correspondence, in the amount not exceeding PLN 30. In the event of the parties not joining mediation, the mediator is entitled to a refund of expenses not exceeding PLN 70.

On the other hand, the remuneration of the mediator, being a taxpayer obliged to settle the value added tax, as specified above, and the mediator's expenses, is increased by the applicable rate of value added tax provided for this type of activity in the provisions on value added tax. Mediation, therefore, is an example of an alternative dispute resolution method, thanks to which the costs of proceedings are lower for the parties than during a normal trial, and there are no costs of attorneys. In addition, due to the use of mediation, litigation becomes cheaper, because it allows the parties to save their time compared to the classic court procedure, which optimizes not only the procedural costs, but also the entire course of proceedings in a given case.

\section{Conclusions}

In summary, it can be said that mediation in civil cases can be carried out using various methods (styles), as dictated by the content of art. art. $183^{3 \mathrm{a}}$ of the CCP. Such a solution implies the possibility of managing legal security in the discussed area, which is practiced by a mediator. The success of the mediation process is determined not only by the will of the parties expressed both with regard to consent to mediation and to active participation in it, but also the way in which the mediator conducts the proceedings. The instruments currently available to the mediator in civil matters in practice - aside from their real impact on increasing the number of mediation proceedings and settlements concluded before the mediator - may in the long run contribute to the idea of organizing the mediators in an independent self-governing body, as long as a uniform, professional training system for candidates and mediators who wish to raise their qualifications can be developed. Apart from that, there must also exist a clear social need to use the services of such legal intermediaries. An important issue in this aspect is also the development of an appropriate formula of cooperation between judges and mediators, so that the content of the settlement prepared by them is correct in substance, and especially, is in accordance with the universally binding law and principles of social coexistence, since these are the only settlements that can be approved by the judges, which in practice would largely optimize the costs of the entire proceeding, which in fact mediation is intended to serve.

\section{References}

Bublienè, R., Vinogradova, I., Tvaronavičienè, M, Monni, S. 2019. Legal form determination for the development of clusters` activities, Insights into Regional Development 1(3): 244-258. https://doi.org/10.9770/ird.2019.1.3(5)

Directive 2008/52/EC of the European Parliament and of the Council of 21 May 2008 on certain aspects of mediation in civil and commercial matters (EU OJ L No. 136 of 24 May 2008, p. 3).

Jurgilewicz, M. 2018. Environmental security management from the perspective of environmental disputes resolution, Modern Management Review XXIII, 25(4). https://doi.org/10.7862/rz.2018.mmr.43

Jurgilewicz, M., Dana, A. 2015. Mediacja jako sposób rozwiązywania sporów prawnych. [Mediation as a way of resolving legal disputes], Warsaw.

Kazansky, R., Andrassy, V. 2019. Conflict resolution approaches towards smart sustainability of internal relations. Entrepreneurship and Sustainability Issues 6(3): 1268-1284. https://doi.org/10.9770/jssi.2019.6.3(29)

Kaźmierczyk, J., Chinalska, A. 2018. Flexible forms of employment, an opportunity or a curse for the modern economy? Case study: banks in Poland. Entrepreneurship and Sustainability Issues 6(2): 782-798. http://doi.org/10.9770/jesi.2018.6.2(21) 
JOURNAL OF SECURITY AND SUSTAINABILITY ISSUES

ISSN 2029-7017 print/ISSN 2029-7025 online

Lax, D.A., Sebenius J.K., 1986. The Manager as Negotiator, New York, USA

Morek, R. 2007. Mediacja i arbitraż. Komentarz [Mediation and arbitration. Comment], Warsaw

Ryskin, L. 1996. Understanding Mediators Orientation, Strategies and Techniques: A Grid for the Perplexed, Harvard Negotiation Law Review 1.

Sebenius J. K. 1992. Negotiation Analyis: A Characterization and Review, Management Science, nr 38

Vinichenko, M.V., Klementyev, D.S., Rybakova, M.V., Malyshev, M.A., Bondaletova, N.F., Chizhankova, I.V. 2019. Improving the efficiency of the negotiation process in the social partnership system. Entrepreneurship and Sustainability Issues 7(1): 92-104. http://doi. org/10.9770/jesi.2019.7.1(8)

Act of 14 June 1960. The Code of Administrative Procedure (Journal of Laws of 2017 item 1257, as amended).

Act of 23 April 1964. The Civil Code (Journal of Laws of 2014, item 121, as amended).

Act of 17 November 1964. The Code of Civil Procedure (Journal of Laws of 2018, item 155, as amended).

Act of 6 June 1997. Executive Penal Code (Journal of Laws of 2017, item 665, as amended).

Act of 6 June 1997. The Penal Code (Consolidated text, Journal of Laws of 2017, item 2204, as amended).

Act of 30 August 2002. Law on Proceedings before Administrative Courts (Journal of Laws of 2017, item 1369, as amended).

Act of 28 July 2005 amending the Act - the Code of Civil Procedure and certain other acts (Journal of Laws of 2005 No. 172, item 1438).

Act of 10 September 2015 amending certain acts in connection with the promotion of amicable dispute resolution methods (Journal of Laws of 2015, item 1595).

Marcin JURGILEWICZ is the Professor at Rzeszów University of Technologym, PL. Head of the Department of Safety Sciences. Research interests: Research interests: internal security, law, mediation.

ORCID ID: orcid.org/0000-0003-2243-2165

Krystyna KMIOTEK is the Professor at Rzeszów University of Technologym in Department of Entrepreneurship, Management and Eco-innovation. Research interests: management, economics.

ORCID ID: orcid.org/ 0000-0002-0760-8380

Robert DANKIEWICZ is Assistant Professor at the Rzeszow University of Technology in Department of Finance, Banking and Accounting. Research interests: finances, economics.

ORCID ID: orcid.org/ 0000-0003-3453-2892

Andrzej MISIUK is the Professor at University of Warsaw, PL. Head of the Department of Security Sciences. Research interests: internal security, police, management.

ORCID ID: orcid.org/0000-0003-1371-6270 